\title{
Development of night time on-farm ventilated potato storage system in Nilgiri Hills of Southern India
}

\author{
Arun Prasath Venugopal*, Aarthy Viswanath and S. Ganapathy
}

Department of Food and Agricultural Process Engineering, Tamil Nadu Agricultural University, COIMBATORE (T.N.) INDIA

Email: arun16foodengg@gmail.com

*Author for Correspondence

Research chronicle : Received : 04.04.2017; Revised : 12.05.2017; Accepted : 25.05.2017

SUMMARY :

Post harvest losses of potatoes can be minimized by maintaining proper temperature and relative humidity in storage environment and removing the respiratory heat and carbon dioxide. As the farmers in Nilgiri district do not have access to cheaper cold storages, alternative methods of storage taking advantage of prevailing weather conditions were investigated. The diurnal variation in temperature at the place of study was in the range of -3 to $14^{\circ} \mathrm{C}$ in November and 12 to $28^{\circ} \mathrm{C}$ in February. Ventilation at flow rate of $0.14 \mathrm{~m}^{3} / \mathrm{min}$ was adequate to cool the bulk of $250 \mathrm{~kg}$ of potatoes to safer limits. The total weight loss at the end of the storage period on the $120^{\text {th }}$ day was highest in ambient storage and least in cold storage. The weight losses were 53, 9.8, 3.6, 14.4, 27.7 and 2.6 per cent under ambient storage, ventilated storage, ventilation with evaporative cooled storage, simple ventilation in pits, traditional storage pit and cold storage, respectively. A similar trend was observed on the physiological loss of weight in the above listed trails. Rotting and sprouting levels were highest in ambient storage and were observed to be 40 per cent and 100 per cent, respectively on the $120^{\text {th }}$ day.

KEY WORDS : Potato storage, Ventilated storage, On-farm storage, Night time ventilation

How to cite this paper : Venugopal, Arun Prasath, Viswanath, Aarthy and Ganapathy, S. (2017). Development of night time on-farm ventilated potato storage system in Nilgiri Hills of Southern India. Internat. J. Proc. \& Post Harvest Technol., 8 (1) : 37-43. DOI: 10.15740/HAS/IJPPHT/8.1/37-43. 